\title{
Tinjauan Hukum Islam Terhadap Kawin Pineng Pada Masyarakat Adat Abung Nunyai
}

\author{
1Firhan, 2Ibnu Irawan \\ 1,2 Pascasarjana Unversitas Islam Negeri Raden Intan Lampung \\ Jl. Yulius Usman, No.20, Labuhan Ratu, Kedaton, Bandar Lampung. 35132. \\ E-mail: firhanmobile112@gmail.com
}

\begin{abstract}
In the customary of low, marriage is a matter that is blessed with kinship, family and community. until now some communities have consistently carried out weddings that are based on the culture of the local community. Pineng marriage to Abung Nunyai in North Lampung is one example of this traditional marriage. The author is interested in researching the marriage practices of indigenous Abung Nunyai and a review of Islamic law regarding the practice of traditional marriage. The purpose of this study was to determine the local culture of the community in marriage, as well as the legal status of implementing the practice of marriage. This research is field research, using al-Urf theory and descriptive analysis method.
\end{abstract}

Keywords: Islamic Law; Married Pineng; Abung Nunyai Customary Community.

\begin{abstract}
Abstrak
Secara hukum, adat pernikahan merupakan urusan yang berkaitan dengan kekerabatan, keluarga dan masyarakat, sehingga sampai saat ini beberapa masyarakat tetap konsisten melaksanakan pernikahan yang berlandasakan kebudayaan masyarakat lokal, salah satunya adalah pernikahan Pineng masyarakat adat Abung Nunyai di Lampung Utara. Hal tersebut yang menarik penulis untuk meneliti terkait praktik pernikahan masyarakat adat Abung Nunyai dan tinjauan hukum Islam mengenai praktik pernikahan adat tersebut. Tujuan penelitian ini adalah untuk mengetahui kebudayaan lokal masyarakat di dalam pernikahan, serta status hukum pelaksanaan praktik pernikahan tersebut. Penelitian ini merupakan penelitian lapangan, dengan menggunakan teori al-Urf dan metode deskriptif analisis.
\end{abstract}

Kata Kunci,: Pernikahan; Kawin Pinen; Masyarakat Adat Abung Nunyai.

\section{Pendahuluan}

Perkawinan menurut Hukum Adat adalah: urusan kerabat, urusan keluarga, urusan masyarakat, urusan martabat dan urusan pribadi dan begitu pula ia menyangkut urusan keagamaan. Perkawinan dalam masyarakat adat merupakan peristiwa yang sangat penting dan sakral. Ikatan perkawinan tidak hanya melibatkan kedua belah pihak suami istri saja, tetapi juga 
menyangkut pihak lain dan dapat memengaruhi keutuhan suatu ikatan perkawinan. ${ }^{1}$

Pada masyarakat Lampung Pepadun pada umumnya dan Abung Nunyai pada khususnya ada beberapa bentuk perkawinan adat, dan salah satu bentuknya adalah pineng. Secara umum, kawin pineng adalah perkawinan yang dilakukan dengan cara lebih dahulu melakukan pineng (lamar) yang ada kalanya calon suami dan calon isteri tidak ada hubungan apa-apa bahkan dapat terjadi antara keduanya tidak saling mengenal satu dengan yang lainnya.

Pada masyarakat adat pepadun, pineng disebut juga sebagai Ibal serbo, Sering kali difahami sebagai perkawian anak raja atau penyimbang atau tokoh dari tokoh adat, Sehingga ketika mendengar pineng yang terpikirkan adalah dari kampung mana atau marga apa yang akan me-minengya. Ribet, mahal dan panjang prosesnya, sehinggga adat pineng ini menjadi menarik untuk diperbincangkan. ${ }^{2}$

Ketika perkawinan pineng harus dilaksanakan dan salah satu pihak (laki-laki) adalah termasuk keluarga yang kurang mampu dari segi ekonomi, maka pada kondisi demikian, akan terjadi usaha mati-matian agar dapat terlaksana meskipun harus melelang segala harta benda yang bisa di jadikan uang, baik itu kebun, ladang, tanah dan bahkan rumah yang ditempatipun dijual atau digadaikan. Bilamana sampai dengan perjanjian yang disepakati pihak laki-laki tidak dapat menebusnya maka akan diambil oleh orang yang meminjamkan uang tersebut. Kejadian semacam ini sering terjadi pada masyarakat Lampung pada umumnya, ini semua demi melestarikan adat istiadat dan budaya dari nenek moyang mereka.

Pada masa dulu tidak jarang ada diantaranya yang rumahnya dijual atau digadaikan untuk biaya pelaksanaan upacara-upacara adat termasuk pineng, karena pineng ini merupakan uapacara perkawinan yang tertinggi, yang memerlukan dana yang banyak, karena mesti menyembelih beberapa ekor kerbau atau sapi untuk upacara di rumah calon mempelai wanita, dan juga harus melaksanakan begawi di rumah mempelai pria yang disebut dengan istilah begawi dijjo dinnei (upacara disana dan upacara disini) dan untuk semua biaya akan di bebankan kepada pihak mempelai pria.

Menurut sebagian masyarakat, latar belakang terjadinya perkawinan pineng adalah; 1) Suatu bentuk usaha kedua pihak keluarga agar rumah

${ }^{1}$ Hilman Hadikusumo, Hukum Perkawinan Di Indonesia (Bandung: Pustaka Prestasi Nasional, 1990), h.190.

2 Wawanacara, St Puceng Mergo, tgl 1 April 2019 jam 17.00 di Kediamannya di Kelurahan Kotabumi ilir. 
tangga anak-anaknya bisa bertahan sampai akhir hayatnya, karena dengan kawin pineng ini jarang sekali terjadi perceraian meskipun terdapat permasalahan yang besar dan rumit. 2) Upaya mendapatkan pasangan yang sesuai dengan kriteria keluarga, yakni yang dapat diharapkan menjadi penerus garis keturunan pada masa yang akan datang. 3) Sebagai upaya pelestarian budaya adat istiadat, khususnya masyarakat Abung Nunyai yang sudah hampir punah.

Kajian serta penelitian mengenai masyarakat adat di provinsi Lampung bukanlah hal baru, beberapa peneliti telah mengkajinya, diantaranya adalah; 1) Aris Yusuf di dalam tesisnya, mengkaji praktik kawin lari pada masyarakat adat di Kabupaten Way Kanan Lampung, serta proses penyelesaian daripada pelarian calon mempelai tersebut. ${ }^{3}$ 2) Widia Aprina di dalam skripsinya mengkaji terkait pernikahan secara sembuni-sembunyi pada masyarakat adat di Desa Mataram, Lampung, serta keabsahannya. ${ }^{4}$ 3) Tormenset Parlindungan di dalam tesisnya mengkaji mengenai praktik kawin lari di Kabupaten Tanggamus serta cara penyelesaiannya. ${ }^{5}$ Beberapa penelitian tersebut secara sederhana telah mewakili kajian pada masyarakat adat lampung, akan tetapi penulis fokus kepada hal-hal yang berbeda dengan sebelumnya mengenai; masyarakat adat Abung Nunyai di Kabupaten Lampung Tengah, yang berisikan kajian mengenai praktik pernikahan, latar belakang, serta tinjauan hukum Islam mengenai praktik tersebut.

Latar belakang tersebut yang menjadikan penulis tertarik untuk meneliti lebih lanjut mengenai budaya masyarakat di daerah tersebut yang penulis rasa hal tersebut beririsan dengan hukum Islam. Pembahasan di dalam artikel akan dilandasi dua topik penting yaitu: 1) bagaimana praktek kawin pineng pada masyarakat adat Abung Nunyai di Lampung Utara? 2) Bagaimana tinjauan hukum Islam dalam menyikapi budaya masyarakat tersebut?

${ }^{3}$ Aris Yusuf. 2012. Pelaksanaan Kawin Lari Pada Suku Way Kanan (Adat Pepadun) Di Kelurahan Tiuh Balak Pasar Kecamatan Baradatu Kabupaten Way Kanan Provinsi Lampung, Tesis Uiniversitas Diponegoro.

4 Widya Aprina. 2019. Dinamika Sebambangan Suku Lampung di Desa Mataram Marga Ditinjau dari Hukum Perkawinan di Indonesia. Skripsi Institut Agama Islam Negeri Metro.

5 Tormenset Parlindungan. 2004. Budaya Kawin Lari Dan Akibat Hukumnya Pada Masyarakat Suku Lampung Pepadun Di Kecamatan Negeri Sakti Kabupaten Tanggamus Propinsi Lampung. Uiniversitas Diponegoro. 


\section{Metode}

Penelitian ini adalah penelitian lapangan (field research), dan merupakan penelitian kualitatif. Pendekatan yang digunakan adalah pendekatan hukum Islam, Yuridis Empiris dengan wilayah penelitian di Provinsi Lampung. Data lapangan sebagai data primer adalah data yang diperoleh secara langsung dari sumber pertama, dalam penelitian ini yang menjadi data primer yaitu hasil wawancara tokoh adat yaitu; Bapak Syahril Isa (St Turunan Migo), Bapak Taufik (Pn Lunas Marga), dan Bapak Imron (Tuan Pujian) secara langsung kepada narasumber yang berperan memberikan informasi mengenai budaya kawin pineng pada masyarakat adat Abung Nunyai di Kabupaten Lampung Utara. Teori yang digunakan adalah teori Maslahat sebagai barometer dalam mengukur kemaslahatan daripada praktik kawin Pineng tersebut.

\section{Kawin Pineng Pada Masyarakat Adat Abung Nunyai}

Perkawinan Pineng adalah suatu proses yang dilalui untuk melaksanakan suatu pernikahan pada masyarkat Lampung Pepadun pada umumnya dan masyarakat adat Abung Nunyai pada khususnya. Adat Perkawinan ini adalah upacara adat yang paling tinggi dan bergengsi, adapun prosesnya adalah sebagai berikut:

Pertama, Pihak Pria. Proses yang dilakukan oleh pihak keluarga calon mempelai pria adalah sebagai berikut: 1) Puppung adalah musyawarah, yaitu mengkompromikan sesuatu dalam rangka pelaksanaan suatu upacara adat atau yang disebut dengan begawi, baik itu begawi seghak asah, bekatan, kughuk turun mandi ataupun munggahi bumi (mepadun), beberapa tingkatanya antara lain: a) Puppung Miyanak, b) Puppung Suku, c) Puppung Aneg. 2) Pemandai Gawi, kegiatan musyawarah yang dihadiri oleh beberapa Desa atau Kelurahan yang yang terikat dengan perjanjian kerja sama, dalam bahasa daerahnya disebut seselangan. ${ }^{6}$ Perwakilan tuan rumah membuka acara dengan dimulai dengan menyampaikan ucapan selamat datang dan terima kasih kepada pada tamu yang hadir, lalu menyerahkan sejumlah uang sebagai pemandai dan galang silo (pemberitahuan dan ganjel sila) uang penghormatan kepada seluruh undangan yang telah hadir. Adapun Jumlah

6 Seselangan merupakan suatu kampung yang terjalin suatu perjanjian kerjasama dalam adat, yang pada garis besarnya Abung Nunyai di Kabupaten Lampung Utara terdiri dari 15 desa (Cahaya negeri, Bumi Nabung, Mulang Maya, Kota Alam, Blambangan, Kotabumi Tiga Gandung: yaitu Kotabumi Ilir, Kotabumi Tengah dan kotabumi Udik, Banjar Agung, Bumi Agung Marga, Pungguk Lama, Gedung Nyapah, Penagan Ratu, Surakarta dan Bandar Abung. 
atau Nominal Uangnya adalah dengan angka kelipatan 60, bisa Rp 60.000,atau Rp 600.000,- atau Rp 6.000 000.-7

Kegunaan uang pemandai adalah sebagai penghormatan kapada para tamu undangan, dan bila sudah bisa diterima olah masyarakat adat yang hadir pada waktu itu, tujuannya adalah, diharapkan nyaman duduknya dan bisa mengikuti sampai selesai acara tersebut kemudian setelah uang hantaran tadi diserahkan atau ditawarkan kepada masing-masing perwakilan anek atau kampung dan masing-masing perwakilan memberikan tanggapan atas apa yang di antarkan atau uang yang disajikan tersebut bisakah diterima atau tidak, bila diterima maka, bagaimana komentarnya begitu juga sebaliknya bila tidak diterima apa sebabnya dan bagaimana atau jalan keluarnya. Bilamana satu kampung melalui perwakilannya tadi telah dapat menerima apa yang disampaikan oleh tuan rumah atau perwakilannya maka akan dimintakan tanggapan dari kampung yang lainnya sampai semua anek atau kampung yang hadir pada acara tersebut telah memberikan tanggapannya bahwa semua dapat menerimanya, maka barulah di bentuk badan penemah gawi (Panitia Gawi). 3) Lapah temui adalah perjalanan menuju ke rumah pihak calon mempelai wanita, satu rombongan besar yang lengkap dengan pakaian adat kebesaran yang mengatasnamakan marga atau kampung. Adapun peralatan yang harus dipersiapkan untuk dibawa menuju ke tempat pihak wanita antara lain: muli makai, menganai makai, juadah bebedeng (dodol yang dibentuk buaya bersisikan uang Logam), sipak uleu, jung/anjung, duit segheh (sesuai permintaan).

Kedua, Pihak Wanita. Proses yang dilakukan oleh pihak keluarga calon mempelai wanita adalah sebagai berikut: 1) Pemandai merupakan musyawarah yang dihadiri oleh beberapa desa atau Kampung atau aneg yang terikat dengan perjanjian kerja sama adat, dalam bahasa daerahnya disebut seselangan. Seselangan maksudnya adalah setiap peristiwa adat baik yang besar ataupun yang kecil sekalipun, mereka semua (Desa yang ada perjanjian kerja sama) harus terlibat meski hanya diwakili oleh beberapa orang tertentu. ${ }^{8}$ 2) Nyambuk Temui, yaitu menerima rombongan keluarga pria, di mulai dari penerimaan di depan balai adat dengan jarak kira-kira lebih kurang 100 meter dengan pencak silat dengan memaikan pisau duo (dua bilah pedang dimasing-masing orang) yang disebut dengan amuk, menuju sesat menarikan pedang sambil menendang bola kai yang dibungkus dengan kain putih, disebut dengan sipak uleu, sebagai napak tilas dari

\footnotetext{
${ }^{7}$ Wawancara Sultan Turunan Migo di kediamannya di daerah Bumi Agung Marga Juli 2019, dan Wawancara Pn Tunas Marga di kediamannya di daerah Desa Penagan Ratu.

8 Wawancara Tuan Pujian di kediamannya di daerah Sesa Pungguk Lama, Juli 2019.
} 
peristiwa mengalahkan musuh yang kepalanya dipenggal dan dibawa pulang dengan cara disepak seperti layaknya bermain bola kaki. 3) Cangget Pilangan yaitu kegiatan yang dilaksanakan pada saat akan melepas salah seorang anggota keluarga yang akan menikah dan akan pergi ke luar desa, mengikuti suami. Cangget Pilangan dilaksanakan pada malam hari setelah acara nyambuk temui (kedatangan pihak mempelai laki-laki). Cangget Pilangan akan dimulai dari setelah magrib dan akan berakhir menjelang pagi. 4) Ngebekas yaitu prosesi pelepasan seorang gadis pergi untuk menikah. Calon mempelai turun dari penakai bersama dengan calon mempelai peria dan langsung naik ketas rato (kereta Kencana) yang sudah dari tadi disiapkan, bila rato letaknya jauh dari penakai, maka calon mempelai wanita akan dibawa dengan panggo jimo (tandu diatas tangan dua laki-laki yang digabung seperti bangku), sementara itu semua keluarga calon mempelai pria sudah siap dengan kendaraannya masing untuk mengiring rato balak ditaghik nago dibayang-bayangi burung garudo menuju kembali ke rumah, diringi oleh tabuhan kolintang disepanjang jalan, sebagai ungkapan rasa gembira kerena telah mendapatkan yang diinginkan. Pada masa dulu sebelum Islam masuk, maka perkawinan adat inilah yang dipakai, yaitu bertemunya di atas penakai dengan menyerahkan sebuah tapis, dan di suap adalah termasuk prosesi perkawinan, dan serah terima payan itu adalah Ijab qabulnya. ${ }^{9}$

Pelaksanaan adalah beberapa hari setelah calon pengantin wanita tiba di rumah calon mempelai pria, paling cepat 2-3 hari, dan paling lambat 2 atau 3 minggu barulah di laksanakan proses perkawinan sesuai dengan kesepakatan kedua belah pihak. Selama masa jeda itulah masing-masing pihak melakukan persiapan karena kelurga pihak wanita akan membawa beberapa peralatan yang menjadi kelengkapan dalam prosesi perkwinan, diantaranya, Lamat pengawinan (kasur lamat), pemenganan, (seperangkat alat makan) mei juadah (nasi beserta rendang, opor ayam dan telur) serta manuk penggang (ayam panggang) yang kesemuanya itu akan dipergunakan pada saat pernikahan berlangsung.

Sementara itu dipihak mempelai pria nguraw (mengundang) sanakfamili, handai taulan dan jiran tetangga untuk dapat mengahdiri pernikahan yang akan dilaksanakan sesuai dengan kesepakatan antar kedua belah pihak. Dalam hal perkawinan ini mutlak dilaksanakan sesuai dengan Hukum Islam. Adapun kegunaan lamat pengawian adalah untuk tempat duduk calon mempelai pria, sedangkan calon mempelai wanita duduk di atas Kutomaro (Kuade) atau di dalam kamar, setelah selesai ijab Qobul maka acara

9 Wawancara Sultan Ratu Tulin di kediamannya di Kelurahan Kotabumi Ilir September 2019. 
selanjutnya adalah musek (suap) kedua memmpelai yang di awali suapan oleh ibu mempelai pria, istri paman, isteri kelamo dan isteri Lebeu, kepada mempelai wanita dan dilanjutkan kepada mempelai pria, suapan ini melambangkan kasih sayang kelurga suami kepada menantu.

Menurut St Turunan Migo, kalimat undangan hendaknya sebagaimana yang telah dikenal dan membudaya, sebagaimana yang dituturkan olehnya: "Sikam di kayun jamo ,aneg. Ago di puskam dendeng di tangan jenganan ..........., jimmeh ditunggu jam 08.00 tigeh jam 09.00, ulat wat sai ago dipubalah." 10

Setelah selesai prosesi Akad Nikah, maka di teruskan denga makan bersama (pangan syara'). Beberapa hari kemudian setelah akad nikah maka di mulailah acara begawi yang prosesnya sama dengan proses begawi pada umumnya yakni dimulai dengan urau pemandai, mepasah, cangget kughuk turun mandi dan mepaudun, keesokan harinya dilakukan acara seghak asah, bekatan, dan kughuk, turun mandi serta mepadun (munggah Bumi) acara ini paling cepat akan berakhir menjelang magrib.

Pada acara tersebut (seghak asah, bekatan, kughuk, turun mandi dan munggah bumi) ini keluarga pihak mempelai wanita manjau (hadir) dengan membawa sesan berwujud dan sesan yang tidak berwujud, (yang bewajud adalah berupa peralatan rumah tangga dan juga kendaraan, dan tak jarang sebuah rumah, sedangkan yang tidak berwujud adalah berupa gelar dan sarana paralatan upacara adat).

Acara akan berakhir setelah pelaksanaan cakak pepadun atau mepadun atau munggahi bumi, dan di berikanlah gelar suttan, kemudian uang adat (penurunan gawi) dbagi menurut aturan turun temurun, pangan kibau di laksanakan. Sejak saat itu resmilah perkawinan pineng dan telah bergelar Suttan, dan gelar Suttan ini akan berubah bilamana kelak anaknya munggahi bumi dan bergelar Suttan pula, maka orang tuanya akan turun dari pepadun dan akan bergelar Pun,Kayai, atau dalem atau sunan, atau minak dan ada pula yang turun jadi Pangeran.

Karena acara begawi di laksanakan di pihak mempelai pria dan juga di pihak mempelai wanita (begawi dijo dinnei) dan inilah acara Perkawinan Pineng Abung Buay Nunyai di Kabupaten Lampung utara yang asli dari zaman dahulu sebelum mengenal adanya uang sebagai alat jual beli. Hal ini

\footnotetext{
10 Wawancara Sultan Turunan Migo di kediamannya di daerah Bumi Agung Marga Juli 2019. Arti daripada kalimat tersebut adalah: "Saya di suruh, ............ dan ........... mengharapkan kehadiran Bapak dirumah ........., besok dari jam 08.00-09.00, karena ada yang ingin dibicarakan"
} 
dapat dibuktikan dengan sejarah bahwa begawi pada masa lalu penurunan (uang adat) berupa pakaian makanan; ula merah, dodol dan siger atau songkok mas).

Dengan proses yang panjang dan melelahkan serta memakan banyak biaya dan melibatkan semua keluarga dan masyarkat dari berbagai desa bahkan dari luar daerah, dan marga, inilah salah satu faktor yang menyebabkan bahwa perkawinan orang Lampung hampir tidak pernah terjadinya perceraian, meskipun terdapat masalah yang berat dalam kehidupan berumah tangga.

Bila terjadi perceraian merupakan bencana dan aib yang besar bukan hanya bagi keluarga besarnya saja, akan tetapi aib satu desa atau kampung, dan jika perkawinannya dengan luar marga maka akan menjadi aib marga tersebut. Selain darpada itu juga faktor lain yang menyebabkan perkawinan orang Lampung relatif lebih langgeng, adalah karena janda orang lampung nyaris tidak menikah lagi dengan orang lampung karena di anggap perceraian itu terjadi adalah di karenakan perempuan atau isteri itu tidak baik dalam mengurus rumah tangga (tecelat/ nyepello).

Adapun bebepara hal yang melatarbelakangi pelaksaaan pernikahan adat Pineng pada masyarakat adat Lampung Nunyai antara lain adalah:

Pertama, keinginan orang tua. Menikah adalah sebuah tanda di mulainya seseorang harus sudah bertanggung jawab atas diri sendiri secara sepenuhnya. Namun, sebelum menikah biasanya orang tua masih ikut berperan dalam kehidupan anaknya terlebih dalam mempersiapkan pernikahan. Mulai dari ikut menyeleksi calon pasangan, memberikan pengetahuan serta arahan-arahan mengenai pernikahan bahkan ikut membantu anak dalam menyiapkan pernikahan. Salah satu bentuk andil orang tua dalam proses pernikahan anaknya adalah dengan melaksanakan Pineng, dilakukan karena sudah menjad adat yang turun temurun, oleh karena itu, anak atau calon pengantin tidak punya pilihan selain mengikuti orang tua melaksanakan proses pernikahan.

Kedua, melestarikan budaya. Budaya sebagai warisan leluhur dari suatu masyarakat hendaknya terus dilestarikan sebagai bagian dari khasanah budaya Bangsa Indonesia yang beragam. Budaya yang sudah ada sejak ratusan tahun bahkan sebelum masuknya agama Islam dan berdirinya Negara Kesatuan Republik Indonesia. Kehadiran budaya bagi masyarakat ketika itu adalah peraturan yang mengatur kehidupan manusia dalam perkawinan. Pada saat Islam masuk, maka budaya tersebut harus diaktualisasikan dengan aturan-aturan agama dan atau negara. Misalnya, 
budaya yang tidak sesuai dengan Hukum Islam, tentunya akan lebih bijak untuk ditinggalkan atau disesuaikan dengan ajaran Islam.

Ketiga, agar lebih berkesan. Banyak orang menginginkan pernikahan yang dilakukan hanya untuk sekali seumur hidup. Untuk itu mereka meyiapkan pernikahan tersebut dengan sebaik mungkin. Banyaknya prosesi atau tata cata pernikahan dengan Pineng menjadikan pernikahan itu lebih berkesan dan meriah, karena prosesi pernikahan yang dilakukan, banyak sekali pihak yang terlibat dan menjadi kenangan dan kebahagian tersendiri.

\section{Tinjuan Hukum Islam Terhadap Pelaksanaan Perkawinan Pineng Pada Masyarakat Adat Abung Nunyai}

Ditinjau dari Hukum Islam ${ }^{11}$ Pelaksanaan perkawinan Pineng masyarakat Lampung Nunyai di Kabupaten Lampung Utara merupakan salah satu upacara tradisional masyarakat Lampung Nunyai. Pelaksanaan pernikahan pineng ini di Kabupaten Lampung Utara masih berlangsung, meskipun pelaksanaannya mulai langka, seiring dengan perkembangan zaman, banyak masyarakat yang cendrung tidak mau repot.

Antara budaya atau adat-istiadat dengan syariat Islam saling berkaitan satu dengan lainnya. ${ }^{12}$ Namun demikian bila ada yang bertentangan dengan ajaran Islam dalam tata cara perkawinan Pineng maka harus segera di musyawarahkan dan dicarikan solusinya sehingga tidak lagi dilaksanakan, sebagaimana contoh: Cangget pilangan pelakasanaannya tidak lagi dimulai setelah shalat magrib tetapi di mulai setelah shalat Isya. Islam telah memberikan ${ }^{13}$ konsep yang jelas tentang tata cara perkawinan berlandaskan al-Qur'an ${ }^{14}$ dan sunah yang sahih. ${ }^{15}$

Pada dasarnya pernikahan yang di lakukan di masyarakat adat Lampung Nunyai di Kabupaten Lampung Utara adalah sesuai dengan peraturan hukum yang ada, yakni pada Undang-Undang Nomor 1 Tahun

11 Irawan, Ibnu \& Jayusman, Jayusman \& Hermanto, Agus. (2019). Fatwa Contribution to the Development of Islamic Law (Study of The Fatwa Institute of Saudi Arabia). FITRAH:Jurnal Kajian Ilmu-ilmu Keislaman. 5. 181-206. 10.24952/fitrah.v5i2.1979. 161AD).

12 Ahmad Rofiq, Hukum Perdata Islam Di Indonesia (Jakarta: Pena Pundi Aksara,

${ }^{13}$ Irawan, Ibnu \& Jayusman, Jayusman. (2019). Mahar Hafalan Al-Qur'an Perspektif Hukum Islam. Palita: Journal of Social Religion Research. 4. 121-136. 10.24256/pal.v4i2.804.

14 Irawan, Ibnu \& Jayusman, Jayusman \& Hermanto, Agus. (2019). Studi Fatwa AlLajnah Al-Daimah Li Al-Buhus Al-Ilmiyah Wa Al-Ifta': Kritik Atas Larangan Mahar Pernikahan Berupa Hafalan Al-Qur'an. Kodifikasia. 13. 320. 10.21154/kodifikasia.v13i2.1834.

15 Amir Syarifuddin, Hukum Perkawinan Islam Di Indonesia Antara Fikih Munakahat Dan Undang-Undang Perkawinan (Jakarta: Kencana Prenada Media Group, 2009). 
1974 Tentang Perkawinan. ${ }^{16}$ Perkawinan Pineng dalam perspektif hukum Islam dipandang memiliki kesamaan:

Pertama, Perkawinan Pineng dilaksanakan sesuai dengan ajaran agama Islam, yang mana syarat dan rukun nikah harus terpenuhi ketika rencana pernikahan tersebut di daftarkan pada Kantor Urusan Agama. ${ }^{17}$

Kedua, Pernikahan dianggap sah jika dalam pelaksanaan ijab qabul dengan tata cara sesuai tuntunan agama sebagaimana telah diatur dalam Undang-undang Perkawinan. Perkawinan Pineng yang dilakukan oleh masyarakat adat Abung Nunyai seluruhnya beragama Islam, tentu saja menggunakan tata cara Islam seperti halnya pernikahan Islam pada umumnya, meskipun pada zaman dahulu pernikahan cukup dengan serah terima di atas penakai saja, ketika itu belum menganut Islam. ${ }^{18}$

Terkait dengan budaya yang ada dalam pernikahan adat dapat dilihat dari teori al-Urf, ${ }^{19}$ sehingga akan di ketahui bagaimana perspektif hukum Islam dalam menilai budaya khususnya dalam pernikahan pineng yang terjadi pada masyarakat adat Abung Nunyai di Kabupaten Lampung Utara. Untuk mengkaji pandangan hukum Islam mengenai berbagai prosesi atau ritual dalam perkawinan Pineng, maka digunakan sebuah kaidah fiqhiyah yang mampu mengantarkan pada pemahaman mengenai hukumnya.

Kaidah fiqhiyah yang digunakan adalah (الأمور بمقاصدها) segala perkara tergantung pada niatnya. ${ }^{20}$

Kaidah di atas memberi pengertian bahwa setiap amal perbuatan, baik berupa perkataan maupun perbuatan diukur menurut niat orang yang berbuat. Dalam perbuatan ibadah, yaitu amal perbuatan dalam hubungannya dengan Allah, niat (karena dan untuk Allah) adalah merupakan rukun, sehingga menentukan syah atau tidaknya sesuatu amal. Sedangkan dalam perbuatan yang ada hubungannya dengan sesama makhluk seperti muamalah, munakahat, jinayah dan sebagainya. Niat adalah merupakan penentu apakah perbuatan-perbuatan tersebut mempunyai nilai ibadah, sehingga merupakan perbuatan mendekatkan diri kepada Allah atau bukan ibadah. Niat harus sudah ada pada permulaan melakukan perbuatan, sedangkan tempat niat adalah di dalam hati, sehingga untuk mengetahui

${ }^{16}$ Muhammad Idris Ramulyo, Hukum Perkawinan Islam: Suatu Analisis Dari UndangUndang No. 1 Tahun 1974 Dan Kompilasi Hukum Islam (Jakarta: Perbit Bumi Aksara, 1996).

17 Teungku Muhammad Hasbi Ash Shiddieqy, Hukum-Hukum Fikih Islam (Tinjauan Antar Mazhab) (Semarang: PT. Pustaka Rizki Putra, 2001).

18 Hadikusumo, Hukum Perkawinan Di Indonesia.

${ }^{19}$ Abu al-Muzafar Mansur bin Muhammad bin Abdul Jabbar Ibnu Ahmad al-Maruzi Al-Sam'ani, Qawati Al-Adillah Fi Al-Usul (Beirut: Dar al-Kutub al-Alamiyah, 1998).

${ }^{20}$ Abdul Karim Zaidan, Al-Wajiz Fi Ushul Al-Fiqh (Baghdad: Dar Al-Arabiyah Li AlTiba'ah, 1977). 
sejauh mana niat dari yang berbuat, harus kita ketahui bukti-bukti yang dapat dijadikan alat untuk mengetahui macam niat orang yang berbuat. Dalam amal kemasyarakatan misalnya, dapat diketahui dengan bukti yang ada, apakah perbuatan tersebut karena Allah atau karena manusia.

Selain itu juga terdapat kaidah fiqhiyyah yang lain, yakni: (العادة محكمة) adat kebiasaan dapat dijadikan hukum. ${ }^{21}$

Kaidah fiqih ini berkenaan tentang adat atau kebiasaan, dalam bahasa $\mathrm{Arab}^{22}$ terdapat dua istilah yang berkenaan dengan kebiasaan yaitu al-'adat dan al-'urf. Adat adalah suatu perbuatan atau perkataan yang terus menerus dilakukan oleh manusia lantaran dapat diterima akal dan secara terus menerus manusia mau mengulanginya. Sedangkan 'Urf ialah sesuatu perbuatan atau perkataan dimana jiwa merasakan suatu ketenangan dalam mengerjakannya, karena sudah sejalan dengan logika dan dapat diterima oleh watak kemanusiaannya. ${ }^{23}$ Kata al-'adah atau al-u'rf menurut Imam Abi al Faid terkadang digunakan dalam satu makna akan tetapi sama dalam bidang ilmu lain. Bahwasannya al-'urf atau al-adah adalah sesuatu yang dianggap baik oleh syarak atau perkara yang dianggap baik. ${ }^{24}$

Djazuli mendefinisikan, bahwa al-'adah atau al-'urf adalah segala sesuatu yang dianggap baik dan benar oleh manusia secara umum (al-'adah al-'amah) yang dilakukan secara berulang-ulang sehingga menjadi kebiasaan. ${ }^{25}$ Al-'Urf ada dua macam, yaitu al-'urf yang shahih dan 'urf yang fasid. 'Urf yang shahih ialah apa-apa yang telah menjadi adat kebiasaan manusia dan tidak menyalahi dalil syara', tidak menghalalkan yang haram dam tidak membatalkan yang wajib. Sedangkan 'urf yang fasid ialah apa-apa yang telah menjadi adat kebiasaan manusia, tetapi menyalahi syara', menghalalkan yang haram atau membatalkan yang wajib. ${ }^{26}$

${ }^{21}$ Husen Hamid Hasan, Nazariyat Al-Maslahat Fi Al-Fqih Al-Islami (Cairo: Dar AlNahdah Al-Arabiyah, 1971).

${ }^{22}$ Irawan, I. (2019). Analysis Of Al-Lajnah Al-Daimah Li Al-Buhus Al-Ilmiyah Wa AlIfta Fatwa Related To The Phenomenon Of Dowry Memorization of Al-Qur'an. Nurani: Jurnal Kajian Syari'ah Dan Masyarakat, 19(2), 261-272. https://doi.org/10.19109/nurani.v19i2.4364

${ }^{23}$ Wahbah Mustafa Al-Zuhaili, Al-Fiqh Al-Maliki Al-Muyassar (Beirut: Dar al-Kalim alThayyib, 2005).

${ }^{24}$ Ibnu al-Hajib Abi Amr Jamaluddin Usman bin Umar bin Abi bakr, Syarh Al-Adhi 'Ala Mukhtashar Al-Muntaha (Beirut: Dar al-Kutub al-Alamiyah, 2000).

${ }^{25}$ Fathurrahman Djamil, Metode Ijtihad Majlis Tarjih Muhammadiyah (Jakarta: Logos Wacana Ilmu, 1995).

${ }^{26}$ Abu Bakr Jalāluddīn Al-Suyūţī, Al-Rad 'Ala Man Akhlada Ila Al-Ardh Wa Jahl Anna Al-Ijtihad Fi Kulli 'Ashr Fardh (Cairo: Maktabah al-Saqafah al-Diniyyah, 2000). 
Suatu adat atau 'Urf dapat diterima jika memenuhi syarat-syarat, tidak bertentangan dengan syari'at, tidak menyebabkan kerusakan dan tidak menghilangkan kemaslahatan, telah berlaku pada umumnya orang muslim.

Dilihat dari segi objeknya, perkawinan Pineng yang dilakukan di Kabupaten Lampung Utara, tergolong dalam al-'Urf al-Amali, yakni kebiasaan masyarakat yang berkaitan dengan perbuatan. Sedangkan jika dilihat segi keabsahannya dari pandangan syara', maka perkawinan Pineng tergolong dalam al-'urf al-sahih, yakni kebiasaan yang tidak bertentangan dengan nash (ayat atau hadis) tidak menghilangkan kemaslahatan mereka, dan tidak pula membawa mudarat bagi mereka.

\section{Penutup}

Pertama, Perkawinan Pineng adalah suatu peroses yang dilalui untuk melaksanakan suatu pernikahan pada masyarakat Lampung Pepadun pada umumnya dan masyarakat adat Abung Nunyai pada khususnya. Adat Perkawinan ini adalah upacara adat yang paling tinggi dan bergengsi, adapun prosesnya adalah sebagai berikut: 1) Pihak pria; Puppung yaitu musyawarah. Pemandai Gawi, musyawarah beberapa daerah adat. 2) Pihak wanita: Pemandai, yaitu musyawarah yang dihadiri oleh beberapa desa atau Kampung atau aneg yang terikat dengan perjanjian kerja sama adat, dalam bahasa daerahnya disebut seselangan. Nyambuk Temui, yaitu menerima rombongan keluarga pria, dengan iringan adat dan pencak silat. Cangget Pilangan yaitu kegiatan adat pada malam hari, pelepasan seseorang untuk menikah. Ngebekas yaitu prosesi pelepasan seorang gadis pergi untuk menikah, dengan simbol naik ke atas rato, dan diringi dengan tabuhan kolintang, sebagai simbol kebahagiaan.

Kedua, Perkawinan Pineng dalam tinjauan hukum Islam adalah tidak menyalahi aturan-aturan tertentu, karena hal-hal yang berkaitan seputar munakahat telah terpenuhi, sedangkan dalam tinjauan al-Urf tradis dan budaya tersebut tergolong dalam al-urf al-amali, dan merupakan al-urf alsahih, sebuah budaya yang dilakukan oleh masyarakat tertentu dan tergolong kepada budaya yang benar, serta layak untuk dilestarikan dalam kehidupan masyarakat adat.

\section{Daftar Pustaka}

Abi Amr Jamaluddin Usman bin Umar bin Abi bakr, Ibnu al-Hajib. Syarh AlAdhi 'Ala Mukhtashar Al-Muntaha. Beirut: Dar al-Kutub al-Alamiyah, 2000. 
Al-Sam'ani, Abu al-Muzafar Mansur bin Muhammad bin Abdul Jabbar Ibnu Ahmad al-Maruzi. Qawati Al-Adillah Fi Al-Usul. Beirut: Dar al-Kutub alAlamiyah, 1998.

Al-Suyūţī, Abu Bakr Jalāluddīn. Al-Rad 'Ala Man Akhlada Ila Al-Ardh Wa Jahl Anna Al-Ijtihad Fi Kulli 'Ashr Fardh. Cairo: Maktabah al-Saqafah alDiniyyah, 2000.

Aris Yusuf. 2012. Pelaksanaan Kawin Lari Pada Suku Way Kanan (Adat Pepadun) Di Kelurahan Tiuh Balak Pasar Kecamatan Baradatu Kabupaten Way Kanan Provinsi Lampung, Tesis Uiniversitas Diponegoro.

Djamil, Fathurrahman. Metode Ijtihad Majlis Tarjih Muhammadiyah. Jakarta: Logos Wacana Ilmu, 1995.

Hadikusumo, Hilman. Hukum Perkawinan Di Indonesia. Bandung: Pustaka Prestasi Nasional, 1990.

Hasan, Husen Hamid. Nazariyat Al-Maslahat Fi Al-Fqih Al-Islami. Cairo: Dar Al-Nahdah Al-Arabiyah, 1971.

Irawan, Ibnu \& Jayusman, Jayusman \& Hermanto, Agus. (2019). Fatwa Contribution to the Development of Islamic Law (Study of The Fatwa Institute of Saudi Arabia). FITRAH:Jurnal Kajian Ilmu-ilmu Keislaman. 5. 181-206. 10.24952/fitrah.v5i2.1979.

Irawan, Ibnu \& Jayusman, Jayusman. (2019). Mahar Hafalan Al-Qur'an Perspektif Hukum Islam. Palita: Journal of Social Religion Research. 4. 121-136. 10.24256/pal.v4i2.804.

Irawan, Ibnu \& Jayusman, Jayusman \& Hermanto, Agus. (2019). Studi Fatwa Al-Lajnah Al-Daimah Li Al-Buhus Al-Ilmiyah Wa Al-Ifta': Kritik Atas Larangan Mahar Pernikahan Berupa Hafalan Al-Qur'an. Kodifikasia. 13. 320. 10.21154/kodifikasia.v13i2.1834.

Irawan, I. (2019). Analysis Of Al-Lajnah Al-Daimah Li Al-Buhus Al-Ilmiyah Wa Al-Ifta Fatwa Related To The Phenomenon Of Dowry Memorization Of Al-Qur'an. Nurani: Jurnal Kajian Syari'ah Dan Masyarakat, 19(2), 261272. https://doi.org/https://doi.org/10.19109/nurani.v19i2.4364

Irawan, Ibnu \& Jayusman, Jayusman \& Hermanto, Agus. (2019). Fatwa Contribution to the Development of Islamic Law (Study of The Fatwa Institute of Saudi Arabia). FITRAH:Jurnal Kajian Ilmu-ilmu Keislaman. 5. 181-206. 10.24952/fitrah.v5i2.1979. 
Ramulyo, Muhammad Idris. Hukum Perkawinan Islam: Suatu Analisis Dari Undang-Undang No. 1 Tahun 1974 Dan Kompilasi Hukum Islam. Jakarta: Perbit Bumi Aksara, 1996.

Rofiq, Ahmad. Hukum Perdata Islam Di Indonesia. Jakarta: Pena Pundi Aksara, $161 \mathrm{AD}$

Syarifuddin, Amir. Hukum Perkawinan Islam Di Indonesia Antara Fikih Munakahat Dan Undang-Undang Perkawinan. Jakarta: Kencana Prenada Media Group, 2009.

Teungku Muhammad Hasbi Ash Shiddieqy. Hukum-Hukum Fikih Islam (Tinjauan Antar Mazhab). Semarang: PT. Pustaka Rizki Putra, 2001.

Tormenset Parlindungan. 2004. Budaya Kawin Lari Dan Akibat Hukumnya Pada Masyarakat Suku Lampung Pepadun Di Kecamatan Negeri Sakti Kabupaten Tanggamus Propinsi Lampung. Uiniversitas Diponegoro.

Wahbah Mustafa Al-Zuhaili. Al-Fiqh Al-Maliki Al-Muyassar. Beirut: Dar alKalim al-Thayyib, 2005.

Wawancara Sultan Turunan Migo di kediamannya di daerah Bumi Agung Marga Juli 2019.

Wawancara Puan Tunas Marga di kediamannya di daerah Desa Penagan Ratu Juli 2019.

Wawancara Tuan Pujian di kediamannya di daerah Sesa Pungguk Lama, Juli 2019.

Wawancara Sultan Ratu Tulin di kediamannya di Kelurahan Kotabumi Ilir September 2019.

Widya Aprina. 2019. Dinamika Sebambangan Suku Lampung di Desa Mataram Marga Ditinjau dari Hukum Perkawinan di Indonesia. Skripsi Institut Agama Islam Negeri Metro.

Zaidan, Abudul Karim. Al-Wajiz Fi Ushul Al-Fiqh. Baghdad: Dar Al-Arabiyah Li Al-Tiba'ah, 1977. 